Article

\title{
Regional Transport Plans: From Direction Role Denied to Common Rules Identified
}

\author{
Francesco Russo * and Corrado Rindone $\mathbb{D}$
}

check for updates

Citation: Russo, F.; Rindone, C. Regional Transport Plans: From Direction Role Denied to Common Rules Identified. Sustainability 2021, 13, 9052. https://doi.org/10.3390/ su13169052

Academic Editor: Hamid R. Sayarshad

Received: 5 July 2021

Accepted: 9 August 2021

Published: 12 August 2021

Publisher's Note: MDPI stays neutral with regard to jurisdictional claims in published maps and institutional affiliations.

Copyright: (c) 2021 by the authors. Licensee MDPI, Basel, Switzerland. This article is an open access article distributed under the terms and conditions of the Creative Commons Attribution (CC BY) license (https:/ / creativecommons.org/licenses/by/ $4.0 /)$.
Dipartimento di Ingegneria dell'Informazione, delle Infrastrutture e dell'Energia Sostenibile, Università degli Studi di Reggio Calabria, 89125 Reggio Calabria, Italy; corrado.rindone@unirc.it

* Correspondence: francesco.russo@unirc.it

\begin{abstract}
This paper concerns transportation planning with a specific focus on the regional level. In the context of spatial and transport integrated planning, the paper proposes a structured and systematic identification of the plans. At the European level, specific indications, prescriptive communications, and finalized funds are given to the national infrastructures by means of the TEN$\mathrm{T}$ plan and program, while a Communication and specific guidelines for the Sustainable Urban Mobility Plan have been published as a useful tool to uniform and compare urban transport planning. However, there are no indications for the planning of transport at the regional scale. This paper focuses on regional transport plans, analyzing the general contents and deepening and comparing the contents related to public transport. A case study of Italy is presented. Reference is made to the national guidelines and therefore to the transport plans approved in Italy by the regions. The Italian experience, and the results evidenced, could be a valid reference for all European or extra-European regions or, in any case, for intermediate territorial planning between the national and local ones.
\end{abstract}

Keywords: transport planning; SUMP guideline; regional transport plans; plan indications

\section{Introduction}

Planning is a complex process that, starting from the knowledge of the current situation, makes conscious decisions with respect to objectives and effects. Where, in the decision set, an alternative is the non-intervention. The current state of the system and those of the plan are studied using suitable tools, such as supply, demand, and interaction models, which allow them to be replicated in a transparent way [1-7].

Transportation planning concerns decisions about the configuration of infrastructure and services at different territorial dimensions [8]. Transportation planning is a component of spatial planning that could be an instrument for establishing long-term, sustainable frameworks for social, environmental, and economic development $[9,10]$. Spatial planning has a regulatory function and a development function to establish directions for urban, regional, and national development, to preserve resources, and to establish incentives for investment [11,12]. According to Agenda 2030 perspectives, transportation planning processes and related decisions should contribute to pursuing the sustainable mobility of people and goods [13]. A good plan contributes to reaching a convergence among theories, rules, and implementation [14]. The process is complete when the planned policies become effective and implementable actions [15].

Many works have been developed on the relationship between planning theory and planning practice. The gap between theory and practice in many contexts was particularly analyzed. One of the approaches is the dynamic one between theory, rules, and application [14]. The theme of the gap between theory and practice and therefore of the solution modality is at the basis of town planning and territorial planning [16-19]. The answers to this great question in the literature have been mainly on an urban scale $[6,20]$, with particular specification for smart cities [21,22]. 
Since 2000, the European Transport Ministers have shared the need to uniform decision-making processes on transport systems towards sustainability. European countries adopt different planning approaches.

The United Kingdom has a strong tradition of spatial planning that links local, regional, and national objectives; the Netherlands increasingly links transport planning to spatial planning; the French experience registers coordinated and coherent service plans instead of sectoral infrastructure plans [23].

In the last years, the European Union (EU), and its executive body the European Commission (EC) have attempted to introduce common standards in the transportation planning process at urban and metropolitan levels, with the guideline for Sustainable Urban Mobility Plan [24]. The introduction of standards could be a tool to facilitate stakeholder engagement and transparency in decision-making.

There is not a common vision of the main elements to a regional transport plan [25]. Broaddus [26] compares the approaches of Germany, Netherlands, France, England, Canada, and Australia regarding land use and transport planning, underlining a variety of efforts at the national, regional, and local scale. In most cases, national policy sets planning frameworks and goals; at the regional and local levels actions are realized following a voluntary basis. In the UK, at the sub-national level, there is no single transportation planning approach, from the centralization model in Northern Ireland to different levels in England, Scotland, and Wales. For instance, Scotland has three transport planning dimensions (national, regional, and local). Regional transport plans specify the national indications and rules through strategies and actions [27].

France also has a long tradition of planning. The state guarantees the respect of general interest adopting a strategic planning approach based on a negotiation process. The planning process evolves by adopting a rational planning approach [28]. There are four levels of government: the national government, the regions, the departments, and the municipalities. At a regional and county level, the planning tool is the Schémas de cohérence territoriale (SCOT) that delineates spatial development priorities over the medium to long-term. The SCoT consists of a framework designed in order to ensure coherence among all government levels (vertical integration) and all sectoral policies (e.g., transport, environment, urban policy, economic development, etc.) (horizontal integration) [29].

Transport planning functions in Germany depend on transport modes. Air transport, federal railways, and maritime shipping are regulated by the federal state (Bund). The states (Länder) are responsible for regional and local public transport. Regional transport plans define the strategic context for the transport system [30].

In Sweden, the National Transportation Administration (NTA) introduced the Regional System Analysis Method description (RSAM). NTA orients national and regional Swedish transport planning. Each region follows a Regional System Analysis Process (RSAP), producing the Regional System Analysis Document (RSAD) with the aim to increase development, sustainability, health, etc. [31].

Italy has a three-level planning structure: national, regional, and local; in the last decade, the metropolitan planning level has been introduced. Italy has provided indications for regional planning, within the framework of the National Plan defined in the General Plan of Transport and Logistics (PGTL) [32].

In the context of territorial planning, public transport plays an important role which in European countries becomes decisive in the management policies of urban, metropolitan, and regional areas. This role is particularly studied in the period of the COVID-19 pandemic, because public transport, due to the characteristics of reducing interpersonal distance, can be a place of contagion and therefore needs adaptations [33]. Despite the adaptations, public transport has reduced its modal share compared to private transport [34]. Although these problems have arisen, public transport (road and rail) is always the pivot of local and regional mobility; from small [35] and large urban areas [36], to metropolitan and regional areas. This centrality derives from the ability it has to best respond to economic, 
social, and environmental issues [37], and therefore to sustainable development as defined in the 2030 Agenda.

It emerges that the different countries need to develop proposals for transport planning at the regional scale. At the European level, very strong indications have been given for the definition of planning on a national and urban scale, while there are no homogeneous indications for the drafting of regional plans. This fact is particularly delicate and contradictory, because the EC, in order to send funds to the regions, asks for the regional plans to be approved, without the existence of a unitary general framework provided by Europe itself, as well as for the SUMP [38] or for the TEN-T.

It is therefore only the Swedish experience to be recalled for regional planning, but in the work of [31] only some indications of the relationship between theory and applications are reported and, however, they refer to 3 regions out of 20 in Sweden. Therefore, on the one hand, there is no systematic analysis of regional transport planning in the literature, and on the other, the proposed guidelines [39] are only of a theoretical nature without any comparison with reality. So, this work, in the first instance, brings something new to scientific knowledge in relation to the literature cited and, in the second instance, it reports complete analysis for all regions of a European country. This work fills the gap caused by this lack of analysis. From the point of view of the proposals the work of Adell and Ljungberg [39], who proposed to also extend the SUMP to territorial areas where there are more cities but all of them small. In this case, the proposal is only theoretical and no reference is given to the real case.

The lack of a unified European framework for regional transport planning is even more serious when one considers that public transport is the backbone of transport systems of this scale.

This lack is particularly important because it not only represents a lack in the definition of perspectives that the European Community often provides to all countries, but an important lack in the overall structure of territorial planning, which also has a strong impact on economic planning. All this translates into the role of direction on a regional scale, in this way not carried out and therefore denied.

This paper contributes to identifying common rules at the regional level identifying dimensions and variables that uniquely specify a generic transport plan. From this identification it is clear the central role of the regional plan between the national and the local. The study case of the regional transport plans adopted in Italy is presented, considering the national unifying indications.

The novelty of the paper stems from the identification of a serious gap in the normative and in the literature, regarding the absence of indications for regional planning. From this lack, the paper analyzes a particularly significant case, the Italian case, where the state has provided some framework indications and regions have prepared the plans. The other goal of the paper concerns the identification of the main characteristics of a regional transport plan and, within the plan, the characteristics that the planning of collective passenger transport must have.

It is clear that if the study of all the Italian regions constitutes an excellent starting point, it is not the point of arrival. More work is needed which, by studying what is happening in other European regions, will allow us to overcome the limitations due to studies in a single country.

While clearly considering this limitation, the paper defines an approach that can be used with good results, in other countries or at the EU level, both to compare the approved regional plans, and to examine the merits of the plan components and their relations with plans of another scale, overcoming the serious limitation of the overall European planning structure.

The work is useful both for technicians and politicians who should fill this gap and for technical designers and researchers who can find in the Italian regional plans a systematic reference point for the drafting of transport plans in other regions. 
The paper, after its introduction, in which the problem of the lack of European Community (supranational) indications for regional transport plans was addressed, is made up of three sections. Section 2 reports the formulation of the problem by identifying the main elements that characterize the dimensions of transport planning and the main indications from community planning to national and urban planning. Section 3 reports the main results obtained from the revision of the regional transport plans adopted in the Italian regions; the results obtained from the analysis of the case study can be seen as a first step in a path towards a uniform planning of regional transport as an integrated process with the SUMPs and the TEN-Ts. The final section summarizes the concluding observations, the current limitations, and future developments.

\section{Problem Formulation: Planning Dimension and EU Unification}

\subsection{Planning Dimensions}

To identify a generic transport plan, it is possible to identify the following dimensions:

- the spatial or territorial dimension, that is a function of the area affected by the plan; at this dimension, plans are generally classified as national $(\mathrm{N})$ or interregional plan, referring to a transportation system of a nation or a region or of a set of regions with planning agreement; regional (R), referring to a transportation system of a region; local (L), referring to a transportation system of a town or aggregation of more than one town;

- the temporal dimension, that is a function of the needed time for implementing the plan, and achieving the goals; it is generally classified as long-term or strategic (S), referring to interventions that modify the structure of the transportation system and that require long times and considerable financial resources; medium-term or tactical (T), referring to managerial interventions relative to optimal resource allocation; short-term or operative $(\mathrm{O})$, referring to interventions to be made in a brief time scale;

- the deepening dimension, that is a function of detail planned decisions and then depending on the aggregation's level quantitative analyses that supporting decision makers; it is generally classified as a master $(\mathrm{M})$ plan which indicates objectives and strategies; a sectorial (Se) plan that includes a broadening of guidelines recommended in the master plan and specifications for single transportation subsystems (railway, roads, ... ) or for specific demand mobility segment; a feasible (F) plan where, for single interventions formulated within the practicable plan, technical and economic feasibility is analyzed.

The first two dimensions are generally well known. The last one is related to the level of detail of analyses that support the process and to quantify potential effects (or objectives) produced by planned actions (or strategies). This dimension evolves from the most aggregate level (master), where it is necessary to identify objectives, strategies, and planned set of actions, to the most disaggregated level, where it is necessary to evaluate the (technical, economic, and environmental) feasibility of a single intervention.

Adopting these three dimensions, it is possible to identify a generic transport plan (P) with the following variables:

$\mathrm{s} \in(1, \ldots, \mathrm{L})$ that is the spatial dimension, with $\mathrm{L}$ the most extended territorial level; $\mathrm{t} \in(1, \ldots, \mathrm{O})$ that is the temporal dimension, with $\mathrm{O}$ the most extended temporal level; $\mathrm{d} \in(1, \ldots, \mathrm{F})$ that is the deepening dimension, with $\mathrm{F}$ the most disaggregate level of detail in the transport analyses.

Considering these variables, the generic plan can be identified with the synthetic formulation:

$$
\mathrm{P}=\mathrm{P}(\mathrm{s}, \mathrm{t}, \mathrm{d})
$$

The transportation planning process evolves through the introduced dimensions. A generic plan could receive indications by a plan produced at another dimension set and produces outputs that could be useful for the following designing process or for other 
plans. Then, adopting the introduced dimensions, it is possible to represent the process evolutions in the space, in the time, and in the depth.

The absence of a product plan at a specific level-as mentioned above-must not hinder the drafting of the products plan of different levels, defined by the three variables $(\mathrm{s}, \mathrm{t}, \mathrm{d})$. The decisions produced by the higher-level plan products do not necessarily have to prevail over the decisions of subordinate plan products. For instance, the subordinateplan product could produce more detailed analyses, adopting more accurate transport models, that highlight critical issues potentially produced by the decisions of higherorder plans.

\subsection{European Unitary Addresses in National and Urban Transport Planning}

European countries have a different history and culture regarding transport planning, as briefly presented in the introduction. The EC and the European Parliament intervened with multiple indications regarding transport policy. The activation of shared policies was initiated with the Maastricht Treaty of 1992 which provides for "a common policy in the transport sector". The main pillar of the common policy is the creation of the large European TEN-T (Trans European Network-Transport), provided for in Article 129b of the Treaty.

The TEN-T is the main backbone of transport in Europe and has had, on the one hand, a series of subsequent additions to the technical definitions, on the other hand, a series of huge funds. The development of the TEN-T in each EU country is strongly interconnected with the development of the individual national first level networks. It follows that the convergence between the policies of the countries and the European policies is maximum, having today substantially the coincidence, in each country, of the main national network with the European one persisting in the same country.

On the other hand, the question of transport on a regional and local scale is different. European countries have different histories in TP in all its forms, from subways to people movers, passing through public transport by road. The net difference is readable from the number of kilometers of infrastructure for metropolitan transport services in the capitals, ranging from $60 \mathrm{~km}$ in Rome to 200 in Paris, 300 in Madrid, and 400 in London. Equally significant differences are highlighted in the development of transport in European cities, and therefore in the development of transport rules and plans.

If the history of urban transport is different between European cities, starting from Maastricht a path of homogenization has developed in relation to the evolution prospects of the cities themselves.

On the basis of the historical differences and the homogeneity of perspective both in the TP and in the development of the cities itself, the European documents can be divided, in relation to their planning support, into two classes:

- Prescriptive, i.e., Regulations, Directives, Decisions. This group sets out a series of boundaries within which the public transport (PT) must move, in particular, economicfinancial stakes concerning the resources that the single state can put to support the PT and management constraints regarding the public-private relationship and therefore to services that must be managed on the market. Basically, the playing field is delimited and the rules of the game are dictated, that is, a series of constraints to be respected are given. The documents relating to TEN-T belong to this group.

- Address, i.e., Green Papers, White papers, Communications, Recommendations. This group of documents is of interest because, unlike the first, it does not implement other prescriptions, but tends to highlight the best development guidelines for cities and the transport systems present in cities at the service of mobility. The documents relating to SUMPs belong to this group.

The documents for the SUMPs, due to their strategic vision content, constitute important references for the development of transport planning at the urban and metropolitan scale.

In December 2013, the EC sent Parliament a Communication on the guidelines to be pursued collectively to move towards competitive and efficient urban mobility in the use 
of resources. Attached to the Communication is a document that defines the elements for the preparation of Sustainable Urban Mobility Plans.

The main points concern:

a) Public transport

b) Non-motorized transport

c) Inter-modality, to integrate the different modes

d) Urban road safety

e) Road transport, including parking

f) Urban logistics

g) Mobility Management

h) Intelligent Transport Systems.

The Communication had a long period of technical preparation, from 2010 to 2013 and was followed, in January 2014 by the publication of the guidelines [40]. Note that the publication of the guidelines confirms the practical-theory-rules dynamic evolution [14]. Where the rules are the guidelines and the theoretical component of collective transport are developed starting from the last decade of the 20th century [41].

The attention towards SUMP is growing throughout Europe and in 2019 the second edition of the guidelines was published [42].

Since 2013, SUMPs have been set up in various cities. The literature reports many in-depth analyses. Among the most interesting works is the special issue of sustainability on SUMP [43] in which experiences of European and Asian cities are compared, and in particular, the paper of Rye and Hrelja [44] which compares policies to reduce the mobility of cars, on the pitch in British, Dutch, German, and Swedish cities. It is useful to recall the work of Jordová and Brůhová-Foltýnová [45] in which it is emphasized, analyzing the cities of the Czech Republic, how the SUMP makes a difference in the management of local transport.

For the TEN-T networks, there is a wide debate in the literature regarding multiple aspects. The railway sector is discussing the development of high-speed networks in Europe, considering what has already been achieved, the results obtained and the significant construction costs [46-50]. While for the railways, the main theme is infrastructural at the opposite extreme, for air transport the theme is that of services. One of the most discussed is that of the intervention with public service obligations in the case of lines operating from low-demand regional airports [50-56]. The port system has achieved stability from an infrastructural point of view for maritime works. Ongoing developments concern the integration of new value-added activities [57-59] and the ability to integrate emerging ICT technologies to improve the performance of traditional activities [60-62].

It therefore emerges that both on a national and urban scale, the EC has given strongly unitary guidelines to the policies of the entire EU territory. A particularly important role in the history and management of European states is that of the regions, which act as an intermediary body between states and cities.

The role of the regions is highlighted by the EU which has the European Committee of the Regions among its most important institutions. Therefore, the regions are present in the history, in the culture, and in the institutions of the states and of Europe. There is a lack of homogeneous guidelines for the regional planning of transport by the EC. It would be useful to have an overall reference framework for all of Europe. The overall homogeneous structure would be particularly useful because the EC often asks the regions, which benefit from direct EU funds, to draw up the transport plan, but in the absence of a unitary EU framework, each plan has different characteristics from the others.

In the next section, Italy is presented as a case study. The indications provided on a national scale for the preparation of regional plans are first recalled and then the real implementations carried out by the regions. 


\section{Problem Solution: The Case of the Italian Regions}

In this paper, with specific reference to Italy, the contents of regional (R), master (M) and strategic (S) plans are presented.

The Italian transportation planning process is analyzed, considering the regional dimension. A national law (D.lgs 422/97) transfers from national government to regions the programming function for many transport sectors, with specific reference to the public transport sector. This transfer gives the possibility to analyze what happens in the sector involved by the law, considering firstly the public transport.

\subsection{Components and Objectives of Regional Plan}

In 2001 the national General Transport and Logistic Plan [32] provided some guidelines to produce a transport regional plan. In recent years, the result is that most of the Italian Regions have concluded the regional transportation planning, following the national addresses. This section presents a review of principal contents of the regional transport plans in Italy.

The technical and administrative acts produced by all Italian regions are analyzed in order to identify main elements. Specific issues are related to inland regions [63].

The first step of analysis concerns the advancements of single plan products respect to the approval process. The main results of a survey based on institutional website of the Italian regions are presented. Most of the regions, in recent years, after the approval of the PGTL, have started and concluded the planning process at least once.

The second step concerns the deepening dimension. In this step, the analyses that support a single regional plan are reviewed. According to European directives, some analyses support Strategic Environmental Assessment (SEA) [64]. The review focuses on transport system analyses in demand, supply, and their interactions. These analyses simulate potential effects of planned infrastructures and services.

The plan's contents are not uniform in all regions and autonomous provinces. Many plans are produced according to the national PGTL's guidelines. These plans report analyses of mobility of people and goods in terms of demand, supply, and their interactions with the objectives to pursue. Results of the analyses support the identification of the principal problems of the transport system and then the actions defined to overcome the current criticalities and achieve the objectives in a future scenario. Transport system models allow analysts to simulate potential effects of the planning's implementation. The simulated results, with different levels of detail, make it possible to measure the level of achievement of the objectives in relation to the different proposed actions.

The expected results obtained are represented by means of quantitative indicators that support the Strategic Environmental Assessment (SEA) process, mandatory for regional transport plans as required by European and national rules.

Table 1 provides a synthetic overview of the general contents of the Italian regional transport plans analyzed in this paper. The analyses are realized with different levels of detail. Table 1, for each region/autonomous province, indicates the presence in the plan of the:

- $\quad$ analyses of people mobility (people mobility);

- $\quad$ analyses of people mobility (freight mobility);

- $\quad$ objectives and targets measurement (objectives measurement);

- environmental reports of Strategic Environmental Assessment (SEA). 
Table 1. Regional transport plans in Italy: general contents.

\begin{tabular}{|c|c|c|c|c|c|c|c|}
\hline Region & Name & Adoption/Approval & Acronym & $\begin{array}{l}\text { People } \\
\text { Mobility }\end{array}$ & $\begin{array}{l}\text { Freight } \\
\text { Mobility }\end{array}$ & $\begin{array}{c}\text { Objectives } \\
\text { Measurement }\end{array}$ & SEA \\
\hline Piemonte & $\begin{array}{l}\text { Piano Regionale dei } \\
\text { Trasporti }\end{array}$ & 2018 & PRT & yes & yes & - & - \\
\hline Valle d'Aosta & $\begin{array}{l}\text { Piano di Bacino di Traffico } \\
\text { 2011-2020 }\end{array}$ & 2010 & PBT & yes & - & - & - \\
\hline $\begin{array}{l}\text { Trentino AA Bolzano } \\
\text { Trentino AA Trento }\end{array}$ & $\begin{array}{c}\text { Piano Provinciale della } \\
\text { Mobilità-Bolzano } \\
\text { Piano Provinciale della } \\
\text { Mobilità-Trento }\end{array}$ & 2018 & PPM & yes & - & - & - \\
\hline Friuli Venezia Giulia & $\begin{array}{c}\text { Piano Regionale del } \\
\text { Trasporto Pubblico Locale }\end{array}$ & 2013 & PRTPL & yes & - & yes & yes \\
\hline Veneto & $\begin{array}{c}\text { Nuovo Piano Regionale } \\
\text { dei Trasporti }\end{array}$ & 2020 & PRT & yes & yes & yes & yes \\
\hline Lombardia & $\begin{array}{c}\text { Programma Regionale } \\
\text { della Mobilità e dei } \\
\text { Trasporti }\end{array}$ & 2016 & PRMT & yes & yes & yes & yes \\
\hline Liguria & $\begin{array}{c}\text { Atto di Programmazione } \\
\text { in materia di trasporto } \\
\text { pubblico locale regionale e } \\
\text { locale }\end{array}$ & 2017 & TPL & yes & - & - & - \\
\hline Emilia Romagna & $\begin{array}{c}\text { Piano Regionale Integrato } \\
\text { dei Trasporti }\end{array}$ & 2019 & PRIT & yes & yes & yes & yes \\
\hline Toscana & $\begin{array}{l}\text { Piano Regionale Integrato } \\
\text { Infrastrutture e Mobilità }\end{array}$ & 2014 & PRIIM & yes & yes & yes & - \\
\hline Umbria & $\begin{array}{l}\text { Piano Regionale dei } \\
\text { Trasporti 2014-2024 }\end{array}$ & 2015 & PRT & yes & yes & yes & - \\
\hline Marche & $\begin{array}{l}\text { Piano Regionale dei } \\
\text { Trasporti }\end{array}$ & 2012 & PRT & yes & - & - & - \\
\hline Abruzzo & $\begin{array}{l}\text { Piano Regionale dei } \\
\text { Trasporti }\end{array}$ & 2016 & PRT & yes & yes & yes & yes \\
\hline Lazio & $\begin{array}{l}\text { Piano Regionale della } \\
\text { Mobilità, dei Trasporti e } \\
\text { della Logistica }\end{array}$ & 2020 & PRMTL & yes & yes & yes & - \\
\hline Campania & $\begin{array}{l}\text { Piano Direttore della } \\
\text { Mobilità Regionale }\end{array}$ & 2014 & PDMR & yes & yes & yes & yes \\
\hline Molise & $\begin{array}{l}\text { Piano Regionale della } \\
\text { Mobilità e dei Trasporti * }\end{array}$ & 2021 & PRMT & yes & - & - & - \\
\hline Puglia & $\begin{array}{c}\text { Piano Regionale dei } \\
\text { Trasporti }\end{array}$ & 2010 & PRT & yes & yes & yes & yes \\
\hline Basilicata & $\begin{array}{l}\text { Piano Regionale dei } \\
\text { Trasporti 2016-2026 }\end{array}$ & 2016 & PRT & yes & yes & - & yes \\
\hline Calabria & Piano Regionale Trasporti & 2016 & PRTM & yes & yes & yes & yes \\
\hline Sicilia & $\begin{array}{c}\text { Piano Regionale dei } \\
\text { Trasporti e della Mobilità }\end{array}$ & 2017 & PRT & yes & yes & - & - \\
\hline Sardegna & $\begin{array}{l}\text { Piano Regionale dei } \\
\text { Trasporti }\end{array}$ & 2008 & PRT & yes & - & - & yes \\
\hline
\end{tabular}

* limited available information.

It is important to point out that:

- all plans consider and deepen the theme of people mobility;

- 13 plans include the freight component;

- 11 plans give quantitative indications for measuring the reach of the plan objectives;

- 10 plans have developed a SEA.

The importance of European indications already emerges from these results. In fact, only half of the plans are equipped with SEAs and just over half indicate the measures to assess the achievement of the plan objectives. It is also significant that only 13 out of 20 plans consider the freight component, which is increasingly important and decisive on a regional scale. On the contrary, it is useful to note that 7 regions have developed the general contents of the plan: Veneto, Lombardia, Emilia Romagna, Abruzzo, Campania, Puglia, Calabria.

\subsection{Plan Links towards Other Plans Considering Public Transport}

Given a generic regional master strategic plan $\mathrm{P}(\mathrm{R}, \mathrm{M}, \mathrm{S})$, it is studied if there are (vertical) specific indications towards up and/or prescriptions towards down and/or (horizontal) towards other regional levels. Then, given a $\mathrm{P}(\mathrm{R}, \mathrm{M}, \mathrm{S})$, it is underlined if it gives planned elements regarding

- the strategic and master level at national or local level (vertical); 
- $\quad$ the tactical and master level at national or local level (vertical);

- the regional and sector level for strategic and tactical level (horizontal).

The three key dimensions of planning are represented in Figure 1, organized in a tree. The tree organization, placing the root in the reference plane R, M, S (regional, master, strategic), allows us to first highlight the interactions of temporal perspective with the other plans: it is evident that a strategic plan is directly confronted with the other strategic plans (S) and with the directly connected tactical plans (T), while it does not dialogue directly with the operational plans $(\mathrm{O})$. Immediately afterwards, the comparison takes place at the in-depth level and therefore with the master (M) and sectorial (Se) plans, but not directly with the feasibility (F). Finally, at the spatial level, on the one hand, with the local scaling plans $(\mathrm{L})$ and on the other with those on a national and international scale $(\mathrm{N})$.

Legend
Space
N: National
R: Regional
L: Local
Time
S: Strategic
T: Tactical
O: Operative
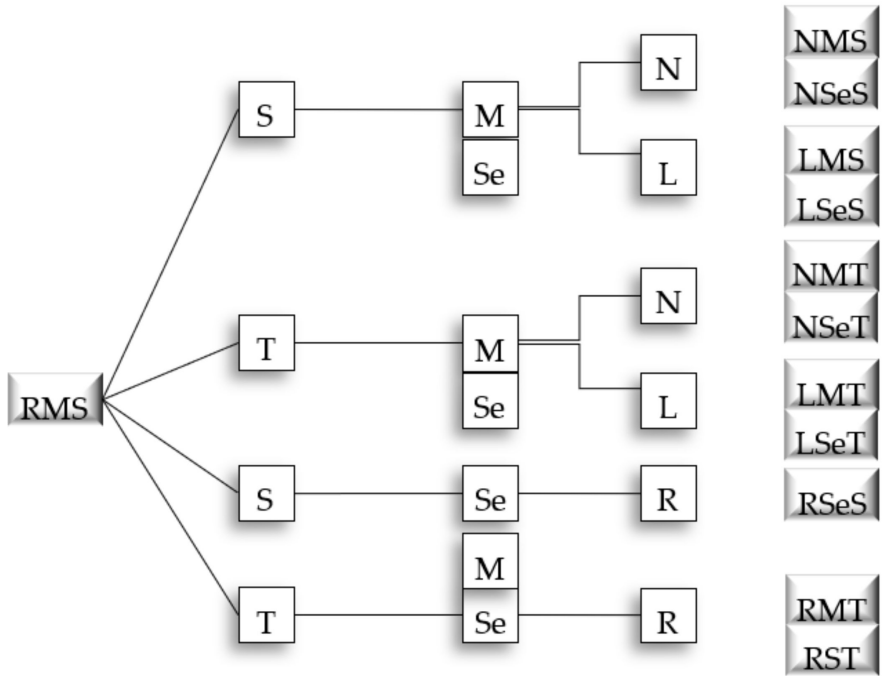

Figure 1. Plan to plan links for the Italian regions.

The role of the transport plan $\mathrm{R}, \mathrm{M}, \mathrm{S}$ is even more highlighted if in addition to the representation of Figure 1, where the root is $P(R, M, S)$, an overall representation of the entire structure of the planes is used. Figure 2 defines the three main dimensions of planning which are arranged in a system of Cartesian axes. In this way, any transport plan specified in the three dimensions can be easily identified. In Figure 2 each transport plan is identified by a small cube, the $\mathrm{P}(\mathrm{R}, \mathrm{M}, \mathrm{S})$ is highlighted in dark gray. The figure shows the transport plans (in light gray) that are directly connected with the regional plan, the other transport plans are in white. On this basis, the interdependencies between the plans are immediately identifiable, for this purpose the links between the various degrees of planning are marked and therefore the explanations, in terms of prescriptive directives or guidelines that each plan must receive from the plans, are already drawn up and prepared for subsequent interventions. Hence Figure 2 shows the links (a, b, c, d, e \& $\mathrm{f}$ ) that the regional plan $P(R, M, S)$ determines with respect to the other planes defined in Figure 1. 

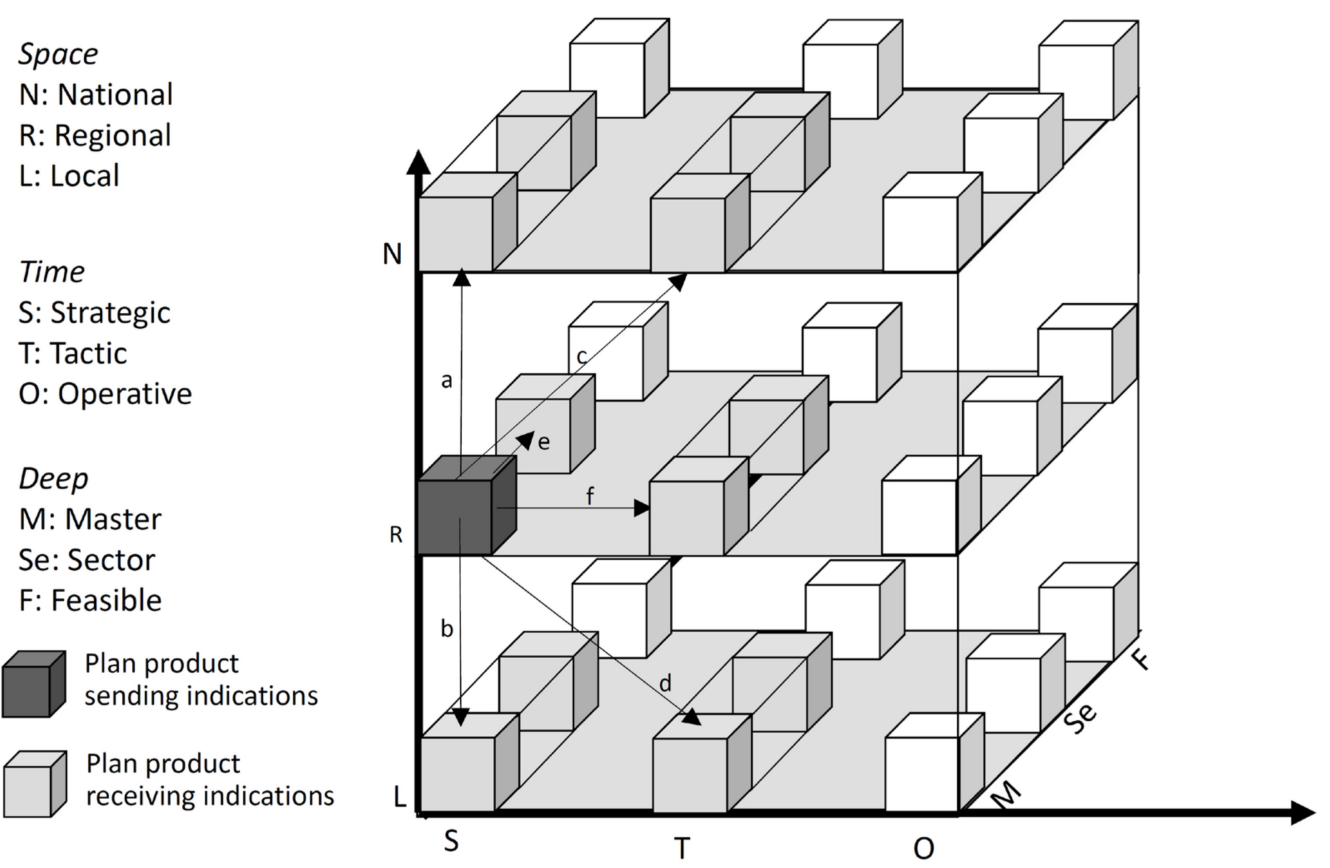

Figure 2. Representation of links a, b, c, d, e \& f from P(RMS) towards other plans.

Figure 2 clearly highlights the limitation deriving from the lack of EC indications. In fact, in the European indications, the whole second level $\mathrm{R}=$ regional is absent. This lack, as already seen above, is somewhat paradoxical because the EC requires regional transport plans, but without having defined a unitary framework and it is equally paradoxical that the EC gives indications for local plans (basic level L), completely skipping the regional plans (level R).

The regional plans provide indications on the different modes of transport, both in relation to infrastructures and services. The reconnaissance presented below concerns in particular public transport (PT) in relation to the different territorial dimensions.

The regions formulate the specific objectives and actions connected to the PT infrastructures and services of their own direct competence. Like the national transport plan, the regional plans report specific addresses for the planning and programming of $\mathrm{PT}$ at the local scale (L, T, Se).

For the two regional (R) and local (L) dimensions, the plans may or not report the indications for the type of connection with the PT at national scale (N, T, Se).

Each plan can report a specification of actions/measures/interventions for the two transport supply components: infrastructures and services.

In the following, it is assumed that the infrastructures are contents of a strategic (S) planning; the services are contents of tactical planning (T). By considering only sectorial (Se) planning related to public transport, actions can be reported at different territorial dimensions $\mathrm{N}, \mathrm{R}, \mathrm{L}$.

Table 2 shows a summary of the specific contents of analyzed plans with reference to specific links for public transport in the sectorial dimension. 
Table 2. General contents of Italian regional plans (R, S, M) for public transport (Se) at different territorial (N, R, L) and temporal dimensions $(\mathrm{S}, \mathrm{T})$.

\begin{tabular}{|c|c|c|c|c|c|c|c|}
\hline & $\begin{array}{l}\text { Space (s) } \\
\text { Time (t) } \\
\text { Deep (d) }\end{array}$ & $\begin{array}{c}\mathrm{N} \\
\mathrm{S} \\
\mathrm{Se}\end{array}$ & $\begin{array}{c}\mathrm{R} \\
\mathrm{S} \\
\mathrm{Se}\end{array}$ & $\begin{array}{c}\mathrm{L} \\
\mathrm{S} \\
\mathrm{Se}\end{array}$ & $\begin{array}{c}\mathbf{N} \\
\mathbf{T} \\
\mathrm{Se}\end{array}$ & $\begin{array}{c}\mathbf{R} \\
\mathbf{T} \\
\mathrm{Se}\end{array}$ & $\begin{array}{c}\mathrm{L} \\
\mathrm{T} \\
\mathrm{Se}\end{array}$ \\
\hline Region & Acronym & a & $\mathbf{e}$ & $\mathbf{b}$ & c & $\mathrm{f}$ & $\mathrm{d}$ \\
\hline Piemonte & PRT & - & yes & - & - & - & - \\
\hline Valle d'Aosta & PBT & - & yes & yes & - & yes & yes \\
\hline $\begin{array}{l}\text { Trentino AA Bolzano } \\
\text { Trentino AA Trento }\end{array}$ & PPM & - & yes & - & - & yes & yes \\
\hline Friuli Venezia Giulia & PRTPL & - & yes & yes & - & - & - \\
\hline Veneto & PRT & yes & yes & & - & yes & - \\
\hline Lombardia & PRMT & yes & yes & yes & - & - & - \\
\hline Liguria & TPL & - & - & - & - & yes & - \\
\hline Emilia Romagna & PRIT & yes & yes & - & - & - & - \\
\hline Toscana & PRIIM & yes & yes & yes & - & - & - \\
\hline Umbria & PRT & yes & yes & yes & yes & yes & yes \\
\hline Marche & PRT & - & yes & - & - & yes & - \\
\hline Abruzzo & PRT & yes & - & - & yes & - & - \\
\hline Lazio & PRMTL & - & - & - & - & - & - \\
\hline Campania & PDMR & yes & yes & yes & - & yes & - \\
\hline Molise & PRMT & - & yes & - & - & - & - \\
\hline Puglia & PRT & yes & - & - & yes & - & - \\
\hline Basilicata & PRT & yes & yes & yes & - & - & - \\
\hline Calabria & PRT & yes & yes & yes & yes & yes & yes \\
\hline Sicilia & PRTM & & yes & yes & - & - & yes \\
\hline Sardegna & PRT & - & yes & - & - & yes & - \\
\hline
\end{tabular}

In order to realize a synthetic comparison among the Italian regional plans, in terms of general and specific contents, an indicator has been introduced that counts the number of "yes" if specific sessions are presented independently from the quantity and quality of the contents.

The indicator of the general contents has a maximum value of 4 if the plan presents analysis of the demand for people and freight mobility, the objectives measurement, and the SEA.

The indicator of specific contents has a maximum value of 6 if the specific contents are developed for the three territorial dimensions for both infrastructures and services.

Therefore, by setting Se = public transport, it has evaluated the relations that the transport plan of the generic region has placed with the other plans, that is, the links of Figure 2. It should be noted that the relationships between the $P(R, M, S)$ and the plans of type $\mathrm{P}(\mathrm{x}, \mathrm{Se}, \mathrm{S})$ indicate whether the infrastructural component of public transport is evaluated in the plan, therefore usually with fixed way (rail). The relationships between $P$ $(\mathrm{R}, \mathrm{M}, \mathrm{S})$ and plans of type $\mathrm{P}(\mathrm{x}, \mathrm{Se}, \mathrm{T})$ indicate whether the collective transport services component is evaluated.

The regions/autonomous provinces with the highest value of the indicators provide specific actions for the regional transport system and in particular for public transport at the national, regional, and local scale.

By considering the indications that the observed RMS plans provide for the strategic (S) and sectorial (Se) dimensions (when the considered sector is the public transport), the results show that:

- $50 \%$ of the plans contain indications for the national dimension $(\mathrm{N})$ activating the link (a);

- $75 \%$ of the plans contain indications for the regional dimension $(\mathrm{R})$ activating the link (e);

- $45 \%$ of the plans contain indications for the local dimension (L) activating the link (b).

By considering the indications that the observed RMSs provide for the tactical (T) and sectorial (Se) dimensions, the results show that: 
- $25 \%$ of the plans contain indications for the national dimension $(\mathrm{N})$ activating the link (c);

- $45 \%$ of the plans contain indications for the regional dimension (R) activating the link (f);

- $25 \%$ of the plans contain indications for the local dimension (L) activating the link (d).

The results obtained show an overall homogeneous framework among the Italian regions, with two regions that give indication for all dimensions: Umbria and Calabria The presence in Italy of a National Master Strategic Plan (NMS), the PGTL 2001, which provides indications for regional plans, produces more than $75 \%$ of compliance for strategic choices. It is interesting to note that only Calabria plan developed the four general contents, presented previously, and the six indications for the other plans.

The indications given for the tactical scale are also interesting, even though the $\mathrm{P}(\mathrm{R}, \mathrm{S}$, $\mathrm{M})$ is of a strategic level, implying a further significant integration.

The results for infrastructural choices, even without prescriptive documents, can be considered as a reference for preparing guidelines on a European scale. The indications for the SUMP at urban level and the obligations for the TEN-T could have evolved, finding the correct balance point, for the drafting of European guidelines for the regional dimension.

Figure 3 highlights the regions, whose plans $\mathrm{P}(\mathrm{R}, \mathrm{M}, \mathrm{S})$ contain indications for the sector plans $\mathrm{P}(\mathrm{R}, \mathrm{Se}, \mathrm{S} / \mathrm{T})$ that the same regions must draw up for public transport (Se = public transport), on the strategic scale (S) on the left, and the tactical scale (T) on the right. It emerges that almost all the regions give indications for the strategic plan, that is for the construction of infrastructures, while only half give indications for the service plans which constitute a direct financial commitment.
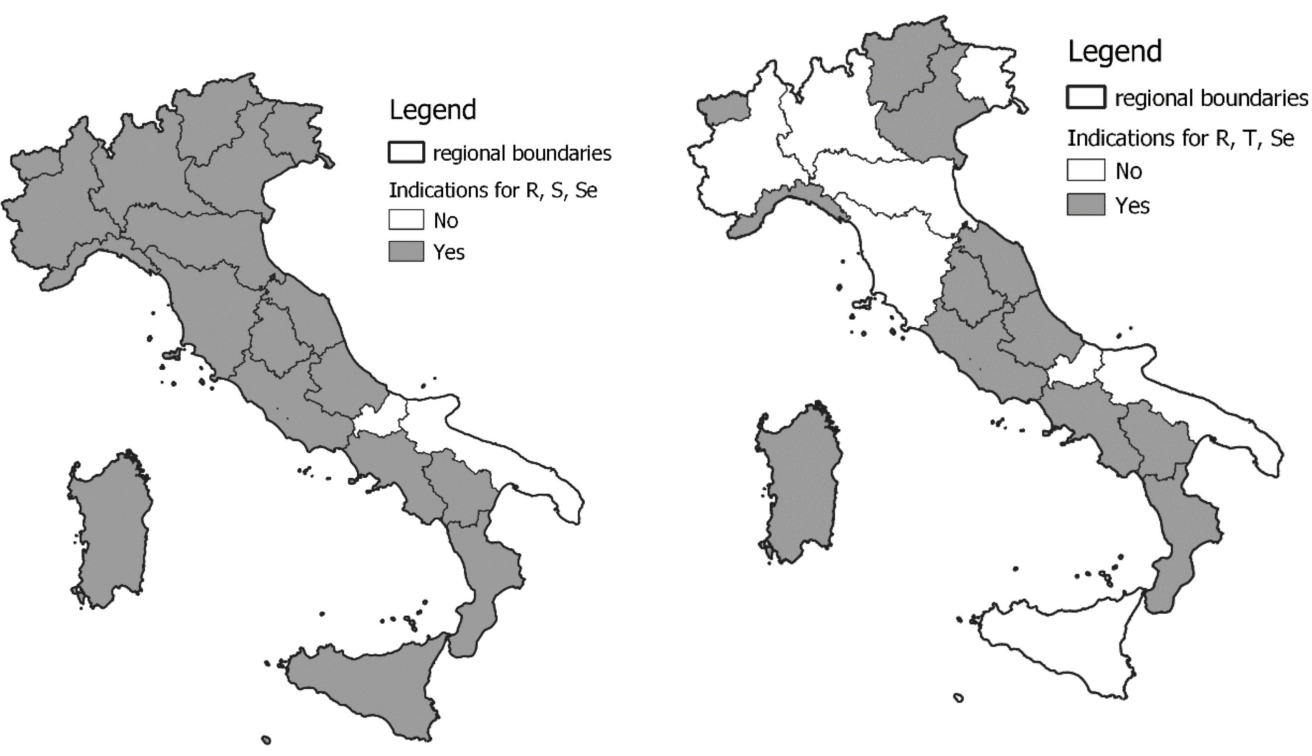

Figure 3. Representation of indications of the $P(R, M, S)$ for public transport (Se) at strategic (S) (left) and tactical (T) (right) scales.

It, therefore, emerges in this case, as before for the main contents, that it is necessary to produce a unitary system of indications. This work, with the common indications that emerged, however, provides a valid basis of reference for the preparation of the plans.

\section{Conclusions}

From what has been presented in the previous sections, it is possible to draw some conclusions. The first concerns the importance of the regional planning, which constitutes a bridge, on the one hand, towards national planning and on the other towards urban planning. The lack of European indications for this level limits the possibility of integrating regional level interventions in transport towards common objectives. Therefore, the TEN-T Program and the Sustainable Urban Mobility Plans are unrelated. 
The second conclusion derives from the analysis of the Italian case study and of the regional transport plans elaborated in Italy. Reference is made to the national guidelines and therefore to the transport plans approved in Italy by the Regions following the guidelines presented with the PGTL. The Italian experience constitutes a valid point of reference for the whole of Europe. From the analysis carried out, comparing the plans, it can be seen that almost all of them analyze both passenger and freight movements, and about half propose a system of quantitative measurement of the results and have been subjected to environmental verification.

Considering the specific field of public transport, the plans give specific prescriptive indications for the infrastructural interventions that must be carried out by the regions and broad indications both for the connections to the national and local plans. Most of the plans also give indications of a tactical level, referring to plans of another temporal level for operational specifications.

The proposed conclusions are an important starting point both for technicians and politicians who should work to overcome this gap and introduce the intermediate level between the national and the local level, both for planners and researchers who have, in the comparisons presented, a precise reference for the preparation of regional transport plans.

As previously seen, the limit of the present work lies in having considered all the regional plans, but of only one country, Italy. In this sense, it may be useful to develop the analysis for other countries. This next work could be carried out on the basis of regional plans sent to the DG Regio of the EC. While considering this limit, the paper defines a methodology that can be validly used in other European or extra-European countries: both to compare the approved regional plans and to examine the merit of the components of the plan and their response.

The future development of the work, in line with what has been presented, concerns the proposition of a nucleus of general indications for the regional plans, or rather for the intermediate plans between national and local. The indications concern both the infrastructural aspects (on wheels and rail) of public transport directly connected to the indications for national and local infrastructures, and the indications relating to services and therefore in the tactical perspective.

Author Contributions: Conceptualization, F.R.; methodology, F.R and C.R.; validation, F.R. formal analysis, F.R.; investigation, C.R.; data curation, C.R.; writing-original draft preparation, C.R.; writing-review and editing, F.R.; visualization, C.R.; supervision, F.R. All authors have read and agreed to the published version of the manuscript.

Funding: This research received no external funding.

Institutional Review Board Statement: Not applicable.

Informed Consent Statement: Not applicable.

Data Availability Statement: See referred papers, not applicable.

Acknowledgments: Special thanks to the three reviewers for their suggestions for improvements: both for the elimination and modification of existing parts, and for the insertion of new parts.

Conflicts of Interest: The authors declare no conflict of interest.

\section{References}

1. Faludi, A. Planning Theory; Pergamon Press: Oxford, UK, 1973.

2. Healey, P.; Williams, R. European urban planning systems: Diversity and convergence. Urban Stud. 1993, 30, 701-720. [CrossRef]

3. Friedmann, J. Planning theory revisited. Eur. Plan. Stud. 1998, 6, 245-253. [CrossRef]

4. Meyer, M.; Miller, E. Urban Transportation Planning: A Decision-Oriented Approach; McGraw-Hill: Boston, MA, USA, 2001.

5. Hall, P.G. Urban and Regional Planning, 4th ed.; Routledge: London, UK, 2002.

6. Allmendinger, P. Planning Theory, 2nd ed.; Palgrave and Macmillan: Basingstoke, UK, 2009.

7. Anthopoulos, L.; Vakali, A. Urban planning and smart cities: Interrelations and reciprocities. In Future Internet Assembly 2012: From Promises to Reality, 4th ed.; Alvarez, F., Cleary, F., Daras, P., Domingue, J., Galis, A., Garcia, A., Zahariadis, T., Eds.; Springer: Heidelberg, Germany, 2012; pp. 178-189. 
8. Russo, F.; Rindone, C. Dalla Pianificazione Alla Progettazione Dei Sistemi Di Trasporto: Processi E Prodotti; Franco Angeli: Milan, Italy, 2007.

9. De Luca, M. Manuale di pianificazione dei trasporti. In CNR—Progetto Finalizzato Trasporti 2, Collana Trasporti; Franco Angeli: Milan, Italy, 2000.

10. Cascetta, E.; Cartenì, A.; Pagliara, F.; Montanino, M. A new look at planning and designing transportation systems: A decisionmaking model based on cognitive rationality, stakeholder engagement and quantitative methods. Transp. Policy 2015, 38, 27-39. [CrossRef]

11. Martin, C.; Evans, J.; Karvonen, A.; Paskaleva, C.; Yang, D.; Linjordet, T. Smart-sustainability: A new urban fix? Sustain. Cities Soc. 2019, 45, 640-648. [CrossRef]

12. ECTP-CEU. European Council of Spatial Planners-Conseil Européen des Urbanistes. Guidelines on Professional Competences in Spatial Planning. 2017. Available online: https://archive.ectp-ceu.eu/ectp-ceu.eu/index.php/en/publications-8/the-charterof-european-planning-214.html (accessed on 12 August 2021).

13. United Nations. The Sustainable Development Agenda. 2015. Available online: https://www.un.org/sustainabledevelopment/ development-agenda/ (accessed on 12 August 2021).

14. Russo, F.; Rindone, C.; Panuccio, P. European plans for the smart city: From theories and rules to logistics test case. Eur. Plan. Stud. 2016, 24, 1709-1726. [CrossRef]

15. Blake, O.; Glaser, M.; Bertolini, L.; Brömmelstroet, M. How policies become best practices: A case study of best practice making in an EU knowledge sharing project. Eur. Plan. Stud. 2021, 29, 1251-1271. [CrossRef]

16. Benevolo, L. Le Origini Dell'urbanistica Moderna; Universale Laterza: Bari, Italy, 1989.

17. Forester, J. Critical Theory and Public Life; MIT Press: Cambridge, UK, 1985.

18. Samonà, G. L'urbanistica E L'avvenire Della Città; Universale Laterza: Bari, Italy, 1959.

19. Taylor, N. Urban Planning Theory Since 1945; Sage: London, UK, 1998.

20. Banister, D. The sustainable mobility paradigm. Transp. Policy 2008, 15, 73-80. [CrossRef]

21. Deakin, M. Smart Cities Governing, Modelling and Analysing the Transition; Routledge: Oxon, UK, 2014.

22. Kitchin, R. Making sense of smart cities: Addressing present shortcomings. Camb. J. Reg. Econ. Soc. 2015, 8, 131-136. [CrossRef]

23. ECMT. European Conference of Ministers of Transport. Assessment \& Decision Making for Sustainable Transport. 2004. Available online: https:/ / www.itf-oecd.org/sites/default/files/docs/04assessment.pdf (accessed on 12 August 2021).

24. ELTIS. Guidelines for Developing and Implementing a Sustainable Urban Mobility Plan, 2nd ed. 2019. Available online: https://www.eltis.org/mobility-plans/sump-guidelines (accessed on 12 August 2021).

25. Matern, A.; Binder, J.; Noack, A. Smart regions: Insights from hybridization and peripheralization research. Eur. Plan. Stud. 2020, 28, 2060-2077. [CrossRef]

26. Broaddus, A. Integrated transport and land use planning aiming to reduce GHG emissions: International comparisons. In Transportation, Land Use, and Environmental Planning; Elsevier: Amsterdam, Netherlands, 2020; pp. 399-418.

27. Marsden, G.; Docherty, I. Governance of UK Transport Infrastructures. UK Government Office for science. 2019. Available online: https://assets.publishing.service.gov.uk/government/uploads/system/uploads/attachment_data/file/78 0871/governance.pdf (accessed on 12 August 2021).

28. Leheis, S. Transportation Planning in France and the challenge of Sustainable Development: Actors, tools and methods. In Proceedings of the XXI AESOP Conference Planning for the Risk Society, Naples, Italy, 11-14 July 2007.

29. EC. European Commission. Easing Legal and Administrative Obstacles in EU Border Regions. Case Study No. 12. Spatial Planning. Obstacles to Cross-Border Public Consultations. 2017. Available online: https://ec.europa.eu/regional_policy/ sources/docgener/studies/pdf/obstacle_border/12_spatial_planning_fr-be.pdf (accessed on 12 August 2021).

30. Fichert, F. Transport policy planning in Germany-An analysis of political programs and investment masterplans. Eur. Transp. Res. Rev. 2017, 9, 28. [CrossRef]

31. Adolphsona, M.; Jonssonb, D. Uncover the theory practice gap in Swedish transport planning: An interdisciplinary approach. Eur. Plan. Stud. 2020, 28, 2237-2260. [CrossRef]

32. PIR, President of the Italian Republic. Decree of the President of the Republic. In Nuovo Piano Generale Dei Trasporti E Della Logistica; Istituto Poligrafico e Zecca dello Stato S.p.A.: Rome, Italy, 2001.

33. Gkiotsalitis, K.; Cats, O. Public transport planning adaptation under the COVID-19 pandemic crisis: Literature review of research needs and directions. Transp. Rev. 2021, 41, 374-392. [CrossRef]

34. Abdullah, M.; Ali, N.; Javid, M.A.; Dias, C.; Campisi, T. Public Transport versus Solo Travel Mode Choices during the COVID-19 Pandemic: Self-reported Evidence from a Developing Country. Transp. Eng. 2021, 5, 100078. [CrossRef]

35. Nigro, A.; Bertolini, L.; Moccia, F.D. Land use and public transport integration in small cities and towns: Assessment methodology and application. J. Transp. Geogr. 2019, 74, 110-124. [CrossRef]

36. Gascon, M.; Marquet, O.; Gràcia-Lavedan, E.; Ambròs, A.; Götschi, T.; de Nazelle, A.; Panis, L.; Gerike, R.; Brand, C.; Dons, E.; et al. What explains public transport use? Evidence from seven European cities. Transp. Policy 2020, 99, 362-374. [CrossRef]

37. Faith-Ell, C.; Fischer, T.B. Strategic environmental assessment in transportation planning. In Handbook on Strategic Environmental Assessment; Edward Elgar Publishing: Cheltenham, UK, 2021.

38. Kiba-Janiak, M.; Witkowski, J. Sustainable Urban Mobility Plans: How Do They Work? Sustainability 2019, 11, 4605. [CrossRef] 
39. Adell, E.; Ljungberg, C. The Poly-SUMP Methodology How to Develop a Sustainable Urban Mobility Plan for a Polycentric Region: Guidelines. Available online: https:/ / poly-sump.eu/fileadmin/files/tool/PolySUMP-SUMP-guidelines-FINAL.pdf (accessed on 12 August 2021).

40. European Commission. GUIDELINES: Developing and Implementing a Sustainable Urban Mobility Plan. Available online: https:/ / www.eltis.org/sites/default/files / guidelines-developing-and-implementing-a-sump_final_web_jan2014b.pdf (accessed on 12 August 2021).

41. Nuzzolo, A.; Russo, F. Modelli per L'analisi e la Simulazione dei Sistemi di Trasporto Collettivo; Franco Angeli: Milan, Italy, 1997.

42. European Commission. Guidelines For Developing and Implementing a Sustainable Urban Mobility Plan Second Edition. Available online: https:/ / www.eltis.org/sites/default/files/sump-guidelines-2019_mediumres.pdf (accessed on 12 August 2021).

43. Burinskienė, M.; Ušpalytė-Vitkūnienè, R. SUMP for Cities' Sustainable Development. Sustainability 2020, $12,8143$.

44. Rye, T.; Hrelja, R. Policies for Reducing Car Traffic and Their Problematisation. Lessons from the Mobility Strategies of British, Dutch, German and Swedish Cities. Sustainability 2020, 12, 8170. [CrossRef]

45. Jordová, R.; Brůhová-Foltýnová, H. Rise of a New Sustainable Urban Mobility Planning Paradigm in Local Governance: Does the SUMP Make a Difference. Sustainability 2021, 13, 5950. [CrossRef]

46. Ben-Akiva, M.; Cascetta, E.; Coppola, P.; Papola, A.; Velardi, V. High Speed Rail Demand Forecasting: Italian Case Study. In Proceedings of the European Transport Conference, Glasgow, UK, 11-13 October 2010.

47. De Rus, G. Economic Analysis of High Speed Rail in Europe, Fundacion BBVA/BBVA Foundation. Available online: https: / / econpapers.repec.org/bookchap/fbbreport/2012126.htm (accessed on 12 August 2021).

48. Hortelano, A.O.; Guzman, A.F.; Preston, J.; Vassallo, J.M. Price elasticity of demand on the high-speed rail lines of Spain: Impact of the new pricing scheme. Transp. Res. Rec. 2016, 2597, 90-98. [CrossRef]

49. Rothengatter, W. Approaches to Measuring the Wider Economic Impacts of High-Speed Rail: Experiences from Europe. In Handbook on High-Speed Rail and Quality of Life; Hayashi, Y., Ram, K.E.S., Bharule, S., Eds.; Asian Development Bank Institute: Tokyo, Japan, 2020.

50. Russo, F. Which High-Speed Rail? LARG Approach between Plan and Design. Future Transp. 2021, 1, 202-226. [CrossRef]

51. Pavlin, S.; Dimnik, I.; Starcevic, M. Influence of low-cost carriers on airport infrastructure development. Promet. Traffic Transp. 2007, 19, 49-54.

52. Donzelli, M. The effect of low-cost air transportation on the local economy: Evidence from Southern Italy. J. Air Transp. Manag. 2010, 16, 121-126. [CrossRef]

53. Benedetti, G.; Gobbato, L.; Perboli, G.; Perfetti, F. The Cagliari Airport impact on Sardinia tourism: A Logit-based analysis. Procedia Soc. Behav. Sci. 2012, 54, 1010-1018. [CrossRef]

54. Dziedzic, M.; Warnock-Smith, D. The role of secondary airports for today's low-cost carrier business models: The European case. Res. Transp. Bus. Manag. 2016, 21, 19-32. [CrossRef]

55. Malavolti, E.; Marty, F. State Aids granted by regional airports: A two-sided market analysis. Transp. Res. Procedia 2017, 25, 30-40. [CrossRef]

56. Russo, F.; Fortugno, G.; Merante, M.; Pellicanò, D.S.; Trecozzi, M.R. Updating National Air Passenger Demand from Traffic Counts: The Case of a Secondary Airport in an Underdeveloped Region. Sustainability 2021, 13, 8372. [CrossRef]

57. UNCTAD. Port Marketing and the Challenge of the Third Generation Port. Available online: https://unctad.org/system/files/ official-document/tdc4ac7_d14_en.pdf (accessed on 3 August 2021).

58. Bichou, K.; Gray, R. A critical review of conventional terminology for classifying seaports. Transp. Res. Part A Policy Pract. 2005, 39, 75-92. [CrossRef]

59. Russo, F.; Musolino, G. Quantitative characteristics for port generations: The Italian case study. Int. J. Transp. Dev. Integr. 2020, 4, 103-112. [CrossRef]

60. Carlan, V.; Sys, C.; Vanelslander, T. How port community systems can contribute to port competitiveness: Developing a cost-benefit framework. Res. Transp. Bus.Manag. 2016, 19, 51-64. [CrossRef]

61. Carlan, V.; Coppens, F.; Sys, C.; Vanelslander, T.; Van Gastel, G. Blockchain technology as key contributor to the integration of maritime supply chain? In Maritime Supply Chains; Elsevier: Amsterdam, The Netherlands, 2020. [CrossRef]

62. Russo, F.; Musolino, G. The role of emerging ICT technologies in the ports: Increasing utilities according to shared decisions. Front. Future Transp. 2021. [CrossRef]

63. Garau, C.; Desogus, G.; Coni, M. Fostering and Planning a Smart Governance Strategy for Evaluating the Urban Polarities of the Sardinian Island (Italy). Sustainability 2019, 11, 4962. [CrossRef]

64. European Commission. Directive 2001/42/EC on the Assessment of the Effects of Certain Plans and Programmes on the Environment (SEA Directive) EC; The Stationery Office Ltd: London, UK, 2001. 